Ching Chao-jung 慶昭蓉

\title{
SI 3662 and SI 3663 - two wedge-shaped Kharoșthī documents from Niya in the Petrovsky Collection*
}

Abstract: Two unedited wedge-shaped wooden documents SI 3662 and SI 3663 (= SI P 138/a and SI P 138/6, respectively) are deciphered in this paper. A preliminary analysis of their content and physical features shows that SI 3663 is very probably the wedge under-tablet to be bound with the wedge covering-tablet N. i. 17 found by Aurel Stein at the N. I. site (Niya, China). SI 3662, a king's instruction issued to Somjaka the Cozbo, is in all probability from the Niya sites, too.

Key words: Petrovsky Collection, Niya documents, Gāndhārī, Kharoșțhī

\section{Introduction}

SI 3662 and 3663 belong to the SI (Serindia) collection of the Institute of Oriental Manuscripts, Russian Academy of Sciences (IOM, RAS). These unedited tablets are in rather good preservation. They lack site marks, and their text is bleached to some degree. Bearing old shelf numbers SI P 138/a and SI P 138/6, respectively, after the name of Nikoloai Fyodorovich Petrovsky (1837-1908), ${ }^{1}$ their existence has been known to Russian scholars. For example, Dr. Margarita Vorobiova-Desiatovskaia's introduction to the SI

(C) CHING Chao-jung 慶昭蓉, Postdoctoral researcher, Centre de recherche sur les civilisations de l'Asie orientale, CNRS / International Research Fellow, Japan Society for the Promotion of Science-Kyoto University (ching.cj@gmail.com)

* I would like to express my sincere gratitude to Prof. I.F. Popova and the Department of Manuscripts and Documents of the Institute of Oriental Manuscripts, Russian Academy of Sciences since 2009. The present paper is one of the results from my project "Dynamics of writing traditions on the Silk Road: A case study of Tocharian and other languages" (Mentor: Prof. Yoshida Yutaka; Host Institute: Department of Linguistics, Kyoto University), during which my consultation on the originals of SI 3662 and 3663 in autumn 2016 was supported by the Kakenhi of the JSPS.

${ }^{1}$ On his outstanding career, see Vorobiova-Desiatovskaia 2004; Popova 2008: 25. 
collection in 2004 - translated by Dr. Jan Nattier into English in 2006 - is extracted as follows: ${ }^{2}$

(1) The N.F. Petrovsky Collection

At present 582 items are registered in the holdings of this collection, for whose study S.F. Oldenburg was principally responsible. Of these, 266 are Sanskrit manuscripts in Brāhmī script on paper... Another 297 are Khotanese manuscripts on paper... Another eleven fragments are in Tokharian. There are two documents on wood written in northwestern (Gāndhārī) Prakrit in the Kharosthi script, and one document on wood with two different scripts: Brāhmī on one side (in the Tokharian B language, = Kuchean) and Kharoșțī (in the Gāndhārī language) on the other. Two documents on wood are written in Old Uighur, in the Uighur script. ...

In addition to the bilingual-biscript tablet, namely SI P/141 (= SI 3672), ${ }^{3}$ the "two documents on wood written in northwestern (Gāndhārī) Prakrit in the Kharoșthī script" no doubt mean the Niya-Gāndhārī ones to be treated below. ${ }^{4}$ In fact, on the occasion of the International Conference "Turfan Revisited" (8-13 September, 2002), Dr. Vorobiova-Desiatovskaia had pointed out the existence of Niya documents in the Petrovsky Collection: ${ }^{5}$

In all, the Petrovsky collection of manuscripts written in Indian scripts contains 582 items. The different languages present therein are: Sanskrit (251 items), Khotanese Saka (297 items), Tocharian B, Old Uighur, Old Tibetan and North-Western Prakrit. The majority of the manuscripts are written in Central Asian Brāhmī script of the southern type. But we also have some wooden documents in Kharosthī script originated from the region of Niya and Kroraina, and wooden documents with text on both sides - Tocharian B in Brāhmī on the recto side and Kharoștịi on the verso side. There is also a unique wooden business document in the Old Uighur language. ...

\footnotetext{
${ }^{2}$ Vorobiova-DesiatovsKaia 2006: 62. Lengthy footnotes are omitted here. On the Khotanese items, see EMMERICK and Vorobiova-DesiatovsKaIA 1993; EMMERICK and VoroBiova-DesiatovsKaia 1995. On the Tocharian ones, see Vorobiova-DesiatovsKaia 1997: 208 for her full list.

${ }^{3}$ Deciphered in SCHMIDT 2001 and re-analyzed in CHING 2013.

${ }^{4}$ The Prākrit used in the documents from the Niya and Loulan sites is now often termed as 'Niya-Gāndhārī'. However, when using abbreviations, I follow ScHMIDT 2001 to denote it by 'NPkt.' (Niya-Prākrit), in contrast to the one found in Kucha by 'KPkt.'

${ }^{5}$ Vorobiova-DesiatovsKaia 2004: 361-362.
} 
During my visits at the IOM in 2009 and 2012, SI 3662 was still kept in a white cardboard box together with the only Kuchean document in the Malov collection, i.e. the wooden tag about monastic wealth SI M-TD/316 (= SI 3664) ${ }^{6}$ while other wooden documents in the Petrovsky Collection had been kept in separate paper envelopes, number by number. SI 3662 and 3664 were delicately embedded into the box with silk cloth lining until their separation into new envelopes around 2014. Since SI 3664 was selected for exhibition, ${ }^{7}$ SI 3662 must have been cherished for a long time as well. In 2015, SI 3663 drew my attention during my consultation of SI 3662. From the photographs kindly provided by the Institute in May 2017 [Fig. 1-4], ${ }^{8}$ readers can easily recognize both their shapes as "wedge under-tablets", in Aurel Stein's terms. ${ }^{9}$ Surprisingly, the content of SI 3663 matches the wedge covering-tablet N. i. 17, which is edited in Kharoșthī Inscriptions Discovered by Sir Aurel Stein in Chinese Turkestan as No. 15. On the other hand, SI 3662 shows some features that imply its scribe's hastiness or lack of experience. There is no doubt as to their genuineness and precious value for Niya studies. ${ }^{10}$

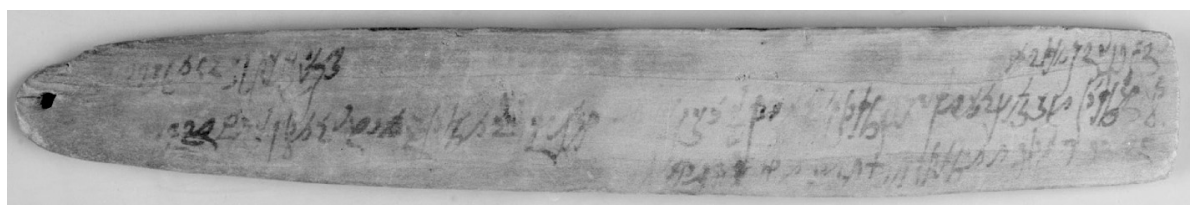

Fig. 1. SI 3662, obverse side (Photo courtesy of the IOM, RAS)

\footnotetext{
${ }^{6}$ See Vorobiova-Desiatovskaia 1997: 206-207 on this piece of "merchandise label", so-called by her. MALZAHN (2007: 278 n. 34) further identified this "commercial tag" in her term as a finding from Miran. In fact, from the content and ductus it can be identified as a label of a samgha's common wealth from a Buddhist site in Kucha, very probably just from today's Kizil grottoes, cf. CHING 2017: 9, 85, 291.

${ }^{7}$ For example, see SEIPEL 1996.

${ }^{8}$ Fig. 5-8 below are all extracted through the red channel of these color photographs by Adobe Photoshop ${ }^{\circledR}$ without further photoshopping, although the text on the original tablets look a little clearer at certain angles to my eye.

${ }^{9}$ Cf. STEIn 1907, esp. 347-352.

${ }^{10} \mathrm{My}$ transcription generally follows the convention given by https://www.gandhari.org/ a_dpreface.php. To the extent possible, the currently preserved text is typed in non-italics. I place all my text restoration and interpretation, including capitalisation and basic punctuation, in italicized format. In my translations, in order to distinguish from personal names, the title or position such as Cozbo or Dvaraka is also italicized.
} 


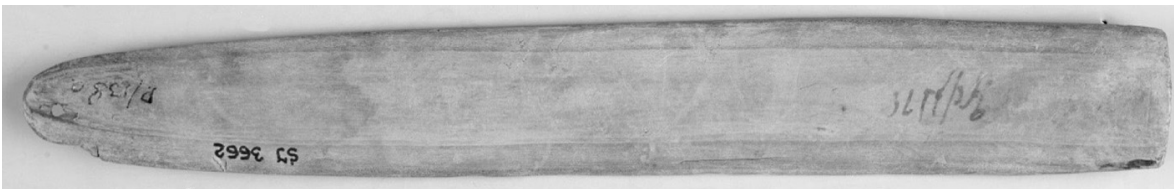

Fig. 2. SI 3662, reverse side (Photo courtesy of the IOM, RAS)

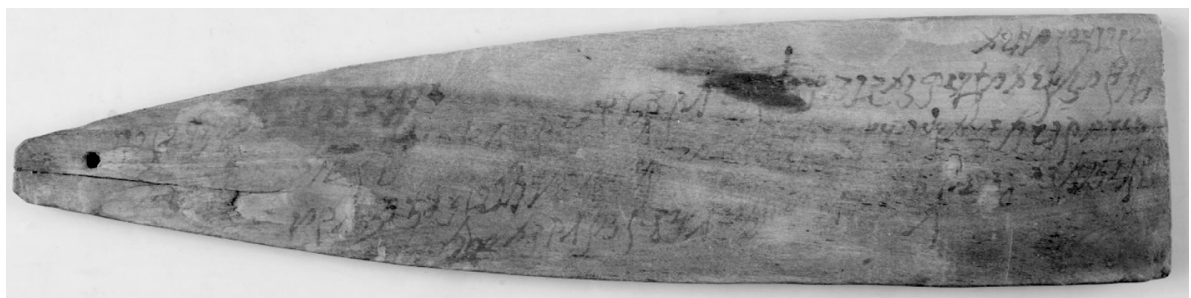

Fig. 3. SI 3663, obverse side (Photo courtesy of the IOM, RAS)

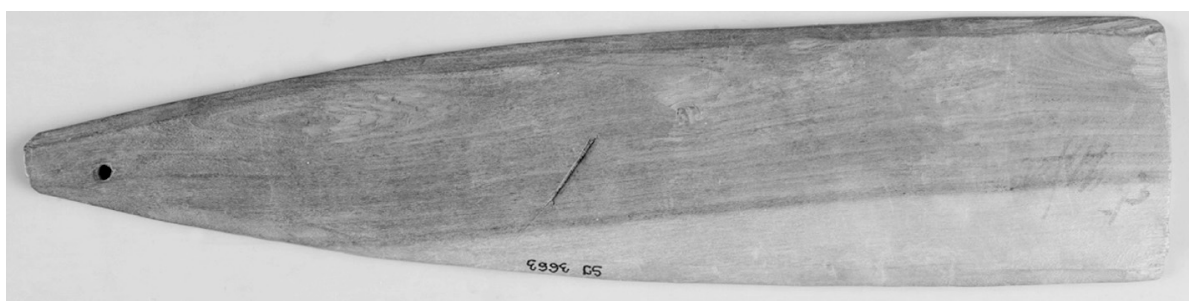

Fig. 4. SI 3663, reverse side (Photo courtesy of the IOM, RAS)

\section{SI $3662(1.3 .2 \mathrm{~cm} \times$ w. $22.8 \mathrm{~cm} \times$ th. $0.5 \mathrm{~cm})$}

Und. Obv.

1 [ma]hanuava maharaya lihati cozbo somjakașa maṃtra deti saca $^{11}$ ah.[n]. ? ?

2 pugo lýipeyasa ca ${ }^{12}$ viṃñave[nt]i yatha dvaraka lýipana ma[tr]eti [yatha] mṛt[a] jaṃna [1].[ip].[m]. ? go 1 taha matreti lýipatga ditaga matreti puna mr[ta]ga yahi e[da] ? ?

\footnotetext{
${ }^{11}$ As pointed out by Burrow (LKD, Index, p. 128) and JAMISON (2000: 77 n. 47), the postposition saça is to be taken as the equivalent of Skt. sacāa, here as an introductory particle meaning 'as follows, thus'. See the next note.

${ }^{12}$ Although one may transcribe Pugo Lýipeya saca 'Pugo together with Lýipeya', scholars have shown that such an accompaniment construction had been reanalyzed to X (zero mark) Y-s $a$ (gen.) $c a$ ' $\mathrm{X}$ and $\mathrm{Y}$ ' and the whole serve as a subject of a 3rd pl. verb, at least in KI No. 419 and a few other documents, cf. JAMISON 2000: $77 \mathrm{n}$. 47. In this paper, saca as the introductory particle of instructions and letters is taken as one word, whereas -s $a$ ca is adopted in the case of accompaniment construction.
} 
$3 \mathrm{mu}$ [dra atra eśati] prațha yati lýipana śa[va]tha ka[v]]iș[y]ati go [1] ș. v.oṣidavo

Und. Rev.

[FAINT TRACES] lýipanenașa ca

\section{Notes}

[U. O. 1] [ma]hanuava maharaya lihati: A blank of $12.5 \mathrm{~cm}$ after this sentence. [U. O. 2] viṃnave[nt]i: Here viṃñavemti 'inform, report'(pres.3pl.) $)^{13}$ is expected. However, the second anusvāra is not written, although the tablet surface below $\underline{v e}$ is slightly scratched, perhaps during its unearthing. Moreover, the final akșāra of this verb looks strange [Fig. 5]. It may denote nti, a ligature so far unknown to scholars, if it is not an inadvertent error of the scribe. ma[tr]eti: This verb is faded, seemingly due to surface friction. [Fig. 5] yatha: There is a dark brown speckle between ya and tha. [Fig. 6] mrrt[a]: The ink spot above $t a$ seems to be a discontinued vocalic remark denoting $i$ or e. [Fig. 6] [1].[ip].[m]. ?: An extremely faint passage denoting a personal name in genitive case based on context. The final akșāra is totally bleached. It can be restored as a cramped sa similar to the one in lýipeyas $a$ in the same line. [Fig. 6] lýipatga: My transcription tga follows Burrow's tǵa with regard to current convention. ${ }^{14}$ [U. O. 3] pratha: The word is written rather cursively. [Fig. 7] ka[v][iș[y]ati: Sic! If in the scribe's mind, karișyati (fut.3sg. of $\sqrt{ } k r$ ) was to be written, he however distorted the tail of the $r$ to the right, making it resemble $\underline{v}$ ( $\dot{v}$ in old convention). [Fig. 7] go [1] ș. v.oṣidavo: The two akșāras after go are clumsy. The scribe may have intended to write vyoșidavo 'to be handed over, to be paid (that is due) ${ }^{15}$ immediately after go, then vyo was altered to the figure 1 and the unfinished $s$ was obliterated, before the gerundive was rewritten afterward. [Fig. 8]

${ }^{13}$ Here and below my translations basically follow Burrow's. Important changes are noted.

${ }^{14} L K D \S 47$. But as GLASS (2000: 61 n. 10) points out, the current situation of rejecting $\dot{n g} a$ ( $\dot{n} g$ a in old convention) could change as the new more Sanskritized documents are studied.

${ }^{15}$ On this verb, cf. $L K D$, Index, pp. 121-122. 


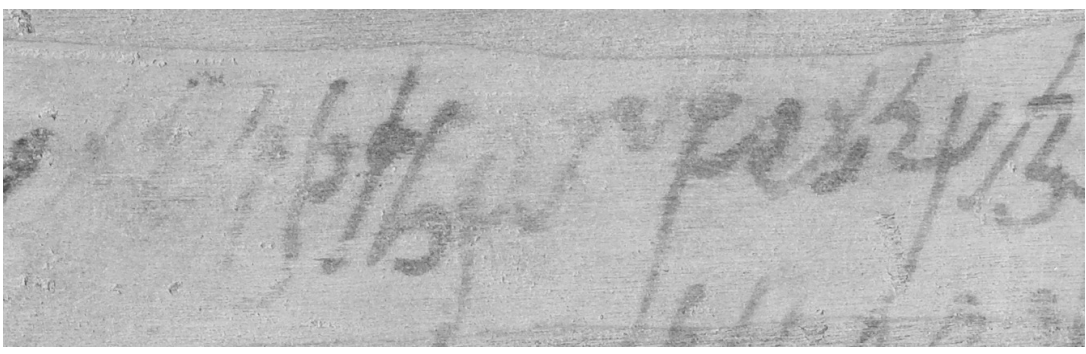

Fig. 5. viṃñave[nt]i yatha dvaraka lýipana ma[tr]eti

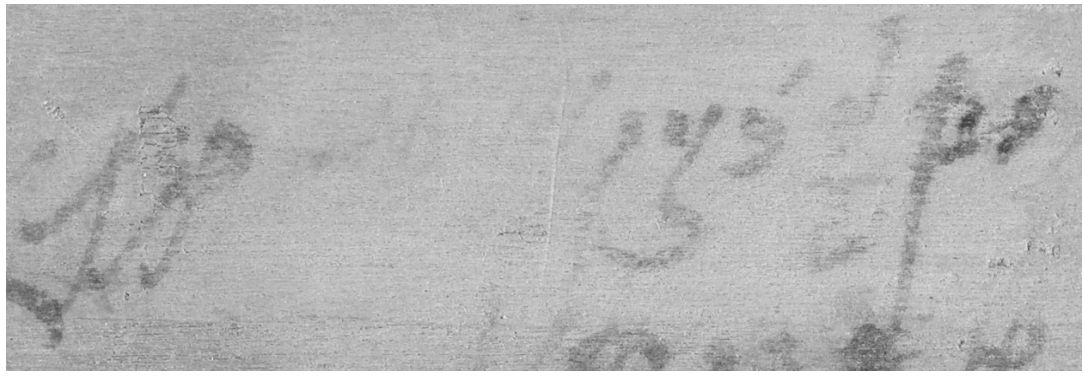

Fig. 6. yatha mṛt[a] jaṃna [1].[ip].[m]. ? go 1

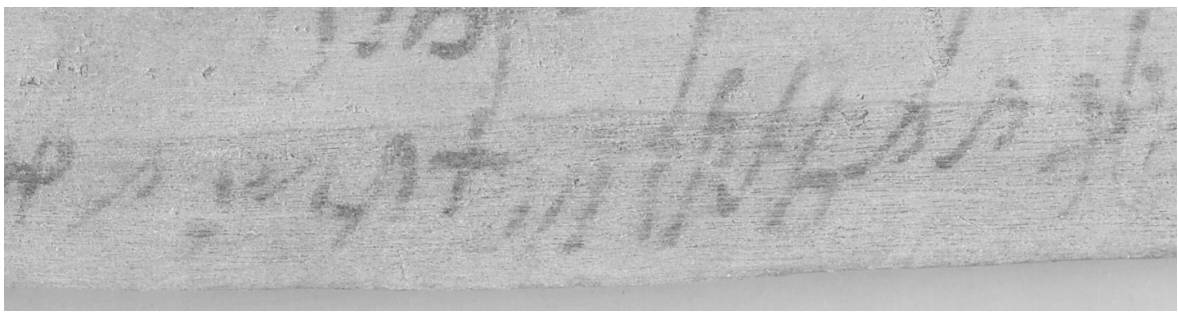

Fig. 7. praṭha yati lýipana śa[va]tha ka[v]iṣ[y]ati

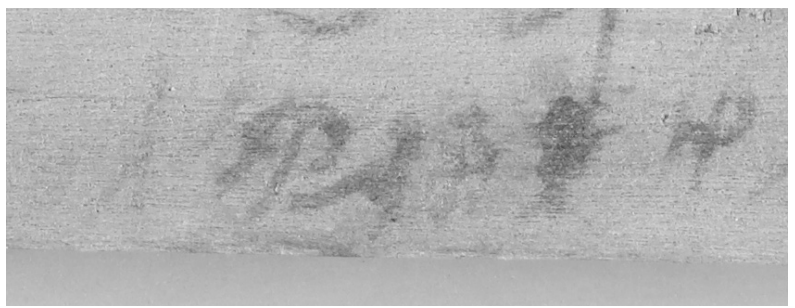

Fig. 8. go [1] ș. v.oṣidavo 
Text restoration with preliminary punctuation and translation

|U.0.1 [Ma]hanuava Maharaya lihati. Cozbo Somjakasa mamtra deti. śaca ah $\left({ }^{*} u\right)[n]\left({ }^{*} o \text { iśa }\right)^{12}$ Pugo Lýipeyas a ca vimñave[nt]i. yatha Dvaraka Lýipana ma[tr]eti. yatha mṛt [a] jamna [L](*y) [ip](*a)[m](*asa) go 1 . taha matreti lýipatga ditaga, matreti puna mr[ta]ga. yahi e[da] $\left({ }^{*} \text { kila }\right)^{\mid 3}$ mu[dra atra eśati], prața yati Lýipana śa[va]tha ka $\left({ }^{*}\right.$ r)iș[y]ati, go [1] s. v( ${ }^{*}$ y)oșidavo.

|U.R. (*Pugo Lýipeya) $\{\{\underline{s}$ a ca $\}\}$ Lýipanenasa ca.

[Main text] His majesty the king writes. He instructs Somjaka the Cozbo as follows: Pugo and Lýipeya inform that Lýipana the Dvaraka makes a statement: "The dead person Lýipama had one cow." Then Lýipatga makes a statement: "It was given (to him)", and again he makes a(nother) statement: "It has died." When this sealed wedge-tablet reaches (you) there, (then) as soon as Lýipana makes an oath, one cow is to be handed over to him.

[Object] Concerning Pugo, Lýipeya and Lýipana. ${ }^{17}$

\section{Discussion}

Since double-wedge documents are highly formulated, the covering-tablet to be bound with SI 3662 should bear a sentence on the obverse side such as Cozbo Somjakas a dadavo/dadavya. Its reverse side would be merely blank or begin with typical formulae, for example atra na paribujiśatu, hastagada (kartavo/kartavya), ${ }^{18}$ iśa visajidavo 'if you are not clear about it there, (the relevant people/things must be taken) in custody and sent (to me) here.' Yet it is difficult to find a tablet of appropriate size to match from other collections. At least it is clear that all the three covering-tablets addressed to Somjaka, ГA1151, 1152 and $1155 \mathrm{kept}$ in the Hermitage, are to be excluded. ${ }^{19}$

\footnotetext{
${ }^{16}$ On $m r \operatorname{ta}$ 'died' and mrtaga 'dead', see $L K D \S 115$. Literally Lýipatga's second statement means the cow '(is) dead'.

${ }^{17}$ Here the text on the reverse side of SI 3662 is to be understood as Pugo Lýipeya Lýipanenas a ca prace (ya) as implied in my translation. The text on the left of Lýipanenas a is severely bleached, but its length can be estimated by very faint traces of $p u$. On the genitive ending added on to the intrumental, see $L K D \S 118$. Also omitted is prace (ya) 'concerning..., in respect of...', a word to indicate the object and/or responsible persons of a document in addition to the addressee(s), on the reverse side of SI 3662 as well as that of SI 3663.

${ }^{18}$ See the full expression hastagada kartavo/kartavya in KI Nos. 33, 223 and 540, etc.

${ }^{19}$ See my preliminary edition of wooden tablets kept in the State Hermitage Museum in 2012, which is to be revised in its English version.
} 
The scribe seems to be inexperienced. Possible errors or clumsy features include: (1) the strange akșāra for the 3rd person plural ending; (2) alteration of mistakenly written *mrte or *mrti to mrta; (3) incorrect writing of karisyati; (4) modification of the text after go 'cow' in order to insert its quantity. This may explain the occurrence of the syntax yatha ... yatha... taha... which looks unusual among Niya documents.

As remarked by Burrow, yatha with the indicative is regularly used in introducing quoted speech. ${ }^{20}$ It is noteworthy that when only yatha is used, the speech is quoted indirectly, i.e. from the king's point of view. For example:

KI No. 52. ahono iśa Lýipeya vincaveti. yatha eșa iśa krasena [sic] dharmena mahi maharayas a uța lișita, tas a nadha coritaga hoati. "Lýipeya reports here now that he dispatched a camel to me the great king to the klasemna arrangements, and its load was stolen."

On some occasions, its coordination with taha described more complicated situations. For instance:

KI No. 63 Lýipeya vimnaveti: yatha atra khakhorni stri 3 nikhalitamti, taha sudha edasa stri maritamti, ..."Lýipeya reports that they took out three witch-women. They killed only the woman belonging to him, ..."

In a few cases, however, not in double-wedge documents, but rectangular ones, as a kind of judgment, the speech is quoted directly after yatha:

KI No. 318 Larsu vimñavita. yatha mahi natha, taha Samgila ni daza Kacanoas a paride nikhalida. "Larsu reported, 'property of mine was lost and was recovered from Kacano, slave of Samgila.",

Needless to say, in KI No. 63 and other similar examples from double-wedge documents, the passage yatha ... taha... delineates a whole statement from a certain person who informs/reports (vi(m)ñaveti) or complains (garahati) to the king. ${ }^{21}$ In SI 3662, I assume that the text from yatha Dvaraka ... until puna mrtaga is Pugo and Lýipeya's quotation of different statements including Lýipana's. The problems to be solved are Lýipana's concern and Lýipatga's role in this matter.

My assumption is based on the usage of the ${ }^{\circ}$ taga participle. As shown by Burrow and Jamison, this extended form of past participle is used frequently

${ }^{20} L K D \S 130$.

${ }^{21}$ Or pres.3pl. vi(m)ñavemti, garahamti, etc., in the case of plural officials or plaintiffs, respectively. In the following discussion on the verb $m a(m)$ treti (Skt. mantrayati) 'he/she says' and $m a(m)$ tremti 'they say', the singular form is taken as the representative one. 
as a passive adjective with a genitive agent. ${ }^{22}$ So, if Lýipatga were the one who gave a cow to Lýipama at an earlier time, or who gave it to someone else after Lýipama's death, he should have been expressed in the genitive (i.e. Lýipatgasa). So it is easier to interpret that Lýipana did not receive - either as Lýipama's relative, creditor or a local officer being responsible of animal husbandry — the cow left by Lýipama, while Lýipatga asserted his ownership and then stated the cow's death. If this interpretation is correct, here we see an unusual order of VS after taha, not to mention the fact that VS is so far unfound with $m a(m)$ treti 'he/she says' in Niya documents.

The function of the denominative verb $m a(m) t r e t i$ is different from $m a(m)$ tra deti 'gives an instruction' that is exclusive to the ruling class. Unlike $m a(m)$ tra deti to be followed by the introductory particle saca, no word is placed between $m a(m)$ treti and quoted speech. ${ }^{23}$ In fact, NPkt. ma(m)tra means not only ordinary speech or official instruction, but also argument and claim. ${ }^{24}$ Hence it seems to me that Pugo and Lýipeya reported different arguments from Lýipana and Lýipatga at the same time, in particular Lýipatga's unwillingness to give his cow away.

The name Lýipama is only attested in KI Nos. 21, 78 and 345 (verso). While the latter two are just name lists, $K I$ No. 21 involves Dhamaśriae's inheritance concerning a cow of which the ownership was shared between her father Lýipama and a man called Kame. ${ }^{25}$ SI 3662 reveals another problem left by Lýipama.

In the corpus of Niya documents, the name Lýipana is attested more often. An Ari-official called such is mentioned in KI No. 767 dated to the 6th regnal year of Vașmana. Another Ari of the same name in KI No. 123 is very likely the identical person, too, of which the text is dated to the 30th year of an unnamed king (possbily Mahiri, i.e. Vașmana's predecessor). If we assume the attestations in Nos. 278, 309 and 450 all indicate the same person, his business

${ }^{22}$ LKD § 119; JAMISON 2000: 71 n. 30, 74 n. 36, 77 n. 47.

${ }^{23}$ Two constructions are observable: (1) $m a(m)$ treti + directly quoted speech (KI Nos. 90, 157 , etc.); (2) indirectly quoted speech $+m a(m)$ treti ( $K I$ Nos. $17,133,515,633$, etc.). It seems that in the second case, so far no finite form is seen, only passive participles in -aya, -ae and gerundives in -davya are attested.

${ }^{24}$ As revealed in the phrase ma(m)tra nikhaleyati '(If anyone) shall bring up arguments (against this deal)' in the contracts $K I$ Nos. $419,437,568$, etc.

${ }^{25}$ See Burrow's translation in $T K D, 5$. Although no further detail is known about Lýipama and his daughter, from SI 3662, Lýipama and Lýipana must be different persons. Padwa's identification of the two (see PADWA 2007: 325) as spelling variants of the same name is questionable, since no other alternation between $m$ and $n$ is provided in his onomasticon. 
and/or official duty would then closely relate to cultivation, storage of grains and collection of land tax. In this case, his claim on a cow would not be surprising: Although his occupation Dvaraka (lit. 'Door/Gate-man') ${ }^{26}$ in SI 3662 is thus far unattested, at least he seemed to be familiar with farming business.

As to Pugo and Lýipeya, the former is once mentioned in KI No. 322 dated to the 21st regnal year of Mahiri. As to the latter, the dates attested span from the 11th year of Mahiri to the 11th year of Vașmana. ${ }^{27}$ Since Somjaka was known to be one of the most active officers during Mihiri's reign, ${ }^{28}$ and given the fact that he had served as a Cozbo as early as the 20th year of Amgoka (KI No. 582), the predecessor of Mahiri, it is safer to date SI 3662 to Mahiri's reign. Nonetheless, the chronology of Ancient Niya is still an open issue, ${ }^{29}$ hence discussion about text dating must be suspended for the moment.

\section{SI $3663(1.5 .6 \mathrm{~cm} \times$ w. $23.8 \mathrm{~cm} \times$ th. $0.7 \mathrm{~cm})$}

Und. Obv.

1 [ma]hanuava maharaya lihati cozbo [ta]ṃjakasa matr[a de]ti saca ahuno iśa

2 lýipeya viṃñaveti yatha edeșa vaṃti krorayammmi [dharmena vaḍa]vi kabhoḍhami tatra kabh.ḍha[mi kolý]isa suḡita[s $\mathrm{s}^{30}$ ca nacira] gachamiti ?

3 me rayaka vaḍavi națamti ima var[ș].mi carapurușa [a]p[ru]ya ? [sa]vida [co]ritaṃti avi ahuno caturtha varșa lýipeyașa ?

4 șavida coritamti sudha ahuno pra[gața] nikh. ? ? kolýișa ni [da]za sutrena cora nikasati yahi eda kila[mutra]

Und. Rev.

1 c[o].bo lýipeyașa

${ }^{26}$ Or a man who serves a local court or office, given the local custom to express 'royal court/palace' by rayadvara.

${ }^{27}$ PAdwA 2007: 130-134; 325-326. Meng (1995: 321) limits Lýipeya's days from the year of Mahiri 21 to that of Vașmana 11, ignoring an attestation of this name in KI No. 637.

${ }^{28}$ MeNG 1995: 308; PADWA 2007: 332.

${ }^{29}$ PADWA (2007, 304-333) generally follows Brough by dating the year Amgoka 17 to 263, after digesting Chapter V of RHIE 1999 (esp. p. 352 n. 57) that summarized different solutions to date that year to 283, 230, 273 276 and 276, respectively by Enoki Kazuo 榎一雄, Nagasawa Katzutoshi 長澤和俊, Ma Yong 馬雍 and Lin Meicun 林梅村. In fact, Ma dated the year to 271 274 rather than 273 276 (cf. MeNG 1995: 368). Furthermore, Meng Fanren 孟凡人 dates the year Amgoka 17 to 269 270 (ibid., 363-388), but his theory has escaped from Rhie's and Padwa's notions. One has to hope that new data from China will shed light on the controversial situation.

${ }^{30}$ Here $\bar{g}$ is used in place of $g^{\ulcorner}$in the traditional convention of $K I$. 
[U. O. 1] [ma]hanuava maharaya lihati: A blank of $11 \mathrm{~cm}$ after this sentence. [U. O. 2] krorayammi: Sic! An error for Krorayinammi/Kroraimnammi 'in Kroraina' [fig. 9]. [dharmena vaḍa]vi: A dark brown spot spans from dha to da. [fig. 9] kabhoḍhami: The $b h$ here can be classified as Type 4 in Glass' scheme. ${ }^{31}$ The next attestation in the same line is too bleached to classify. [Fig. 9 and 11] [U. O. 3] națamti: A newly attested pret. 3pl. 'they

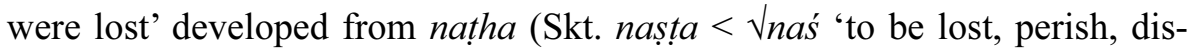
appear, etc.; to cause to be lost or disappear, drive away, remove, etc.'). Here it is so translated instead of 'they perished/removed (the mares)', cf. KI No. 122 Parcona pirovammi go mahamta 1 natha 'One large cow was lost at the for-

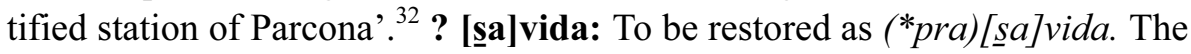
word is translated by Burrow as an adjective 'granted, allowed' as well as a noun 'a grant' derived from pra $+\sqrt{s \bar{u}}$ 'to allow, give up, to deliver' ${ }^{33}$ Presently it is translated as 'produced, released'. ${ }^{34}$ In SI 3663, this adjective means approximately, 'appointed, arranged, assigned (for an action or a task)'. pra[gața] nikh. ? ?: To be restored as pra[gaț] nikh(*aleṃti). Having related the two words to Skt. prakrta- and niṣkālayati respectively, ${ }^{35}$ Burrow interpreted pragata nikhalitamti in KI No. 17 as '(dogs and foxes) fetched out (the treasure) into the open'. The other example in KI No. 211 amceșa palýi na praga[ta] nikhales $i$ was translated by him as 'you are not revealing the tax of other people'. In SI 3663, this phrase seems to indicate that the hunting persons revealed their misbehaviour, as clearly described in the next sentence: Kolýisa's slave drove (or: chased up; lit. 'moved') the stolen mares by rope. [Fig. 10]

${ }^{31}$ GLASS 2013.

${ }^{32}$ Burrow's translation of NPkt. piro/pirova as 'bridge' is widely accepted nowadays, cf. $L K D$, Index, pp. 105-106. However, WEBER (1997: 34-36) has identified it as a loanword from Middle Iranian, cf. Sogdian ptrwp 'fort, post' and Khotanese prūva 'castle'. Since the maintenance of fortified postal stations (usually equipped with beacons) was one of the most important official businesses in ancient Turfan, a similar corvée system imposed on men and animals may have been practiced in ancient Niya and Kroraina, too.

${ }^{33}$ LKD, Index, pp. 107-108.

${ }^{34}$ Pāli pasavita. See https://www.gandhari.org/n_dictionary.php.

${ }^{35}$ See $L K D \S 5$ and Index, p. 101, respectively. 


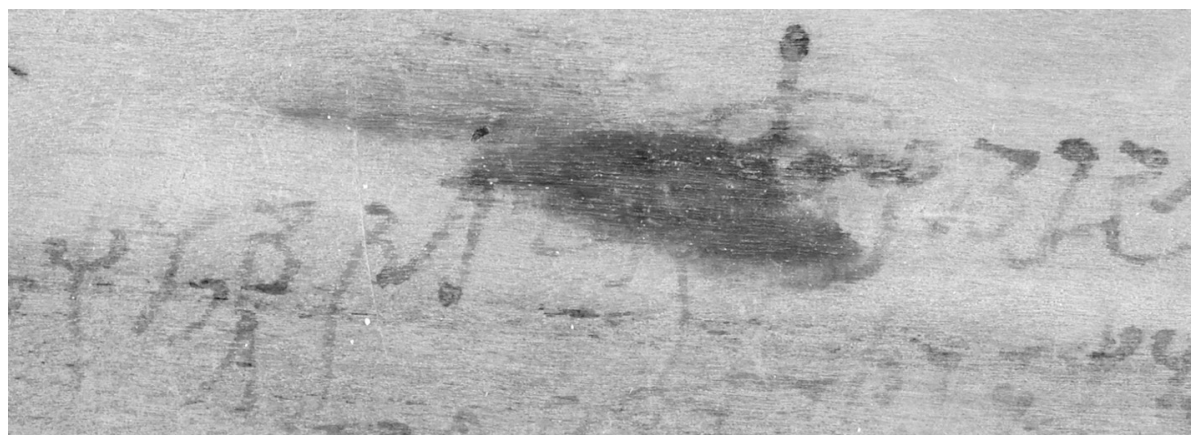

Fig. 9. krorayammi [dharmena vaḍa]vi kabhoḍhami

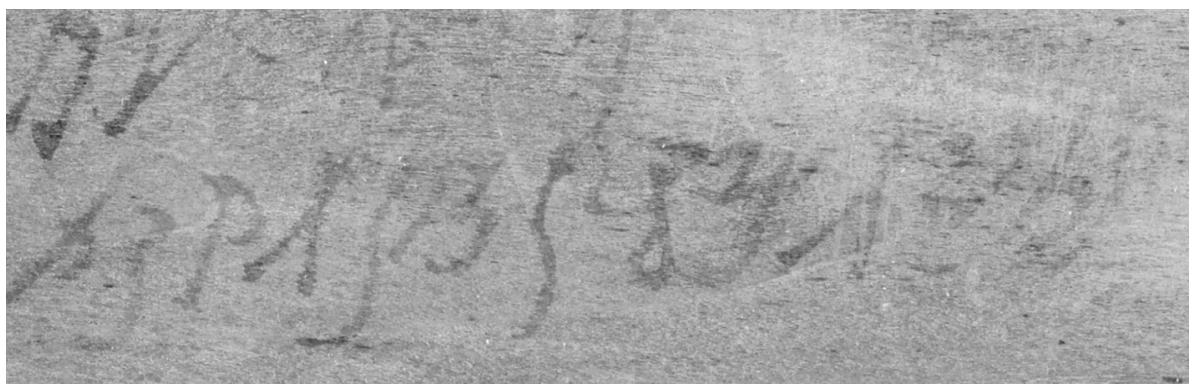

Fig. 10. kolýisa ni [da]za sutrena cora nikasati

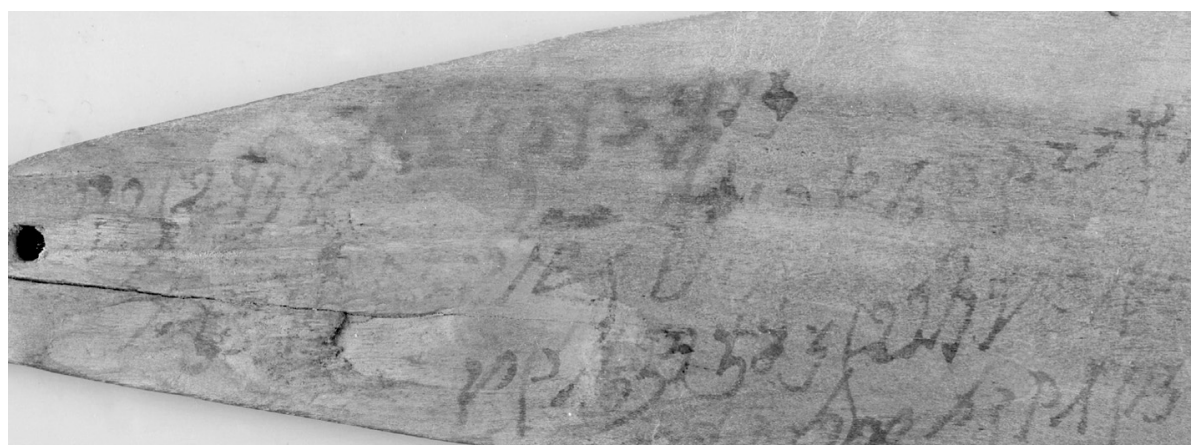

Fig. 11. Left part of SI 3663, obverse side. 
Text restoration,

preliminary punctuation and translation

The word kabhoḍa (loc. kabhoḍami), suggested by Burrow in $L K D$ as 'grazing-land, pasture' and earlier in 1934 as 'some privately owned pasture land', ${ }^{36}$ was attested in $K I$ only in three documents: Nos. 13, 15 and 392. Strikingly, the content and size of SI 3663 (w. $23.8 \times 1.5 .6 \mathrm{~cm}$ ) and those of $K I$ No. 15 (w. $23.5 \times 1.5 .7 \mathrm{~cm})^{37}$ match each other. Although the photograph of $K I$ No.15 is unavailable to this day, it is possible to restore the full text as follows:

\section{SI $3663+$ KI No. 15}

|C.O. Cozbo Tamjakasa dadavo

|U.0.1 [Ma]hanuava Maharaya lihati. Cozbo [Ta]mjakas a matr[a de]ti. saca ahuno iśa ${ }^{12}$ Lýipeya vimñaveti. yatha edeșa vamti Kroray<*in>ammi [dharmena vada] vi kabhoḍami. tatra kabh(*o)ḍhami [Kolýi]şa Sugita[s sa ca nacira] gachamti. $\left({ }^{*} i\right)^{\mid \beta}$ me rayaka vadavi națamti. ima var[ș](*am)mi Carapuruṣa [A]p[ru]ya (*pra)[sa]vida. coritamti. avi ahuno caturtha varșa Lýipeyas a (*pra) ${ }^{\mid 4} \underline{\text { savida}}$ [co]ritamti. sudha ahuno pra[gata] nikh(*alemti). Kolýisa ni [da]za sutrena cora nikasati. yahi eda kila[mutra] ${ }^{\mid \mathrm{C} . R .1}$ atra eśati, pratha Kolýisa Sugitasa ca varidavo, na im ci kabhoụhami nacira gamdavo. ghrida-coritaga prace vivada śavathena sakșiyena samuha ${ }^{12}$ anada prochidavo. avi śamuta prace samuha anada prochidavo, yatha dharmena nice kartavo. atra na paribujiśatu, hastagada iśa visajidavo.

|U.R. C[o](*z)bo Lýipeyas a

[Distination] To be given to Tamjaka the Cozbo.

[Main text] His majesty the king writes. He instructs Tamjaka the Cozbo as follows: Now here Lýipeya informs that by their side, ${ }^{38}$ according to the law

\footnotetext{
${ }^{36}$ LKD, Index, p. 81; BuRrow 1934: 513.

${ }^{37}$ KINo. 15 was described by STEIN $(1907,387)$ as follows: 'N. i. 17 Wedge cov.-tablet $O b v$. $13 / 4$ " from sq. end, seal, standing figure in cameo (prob. Pallas). 11 . Khar. between seal and sq. end, very clear. Usual char. near hole. Rev. 2 ll. Khar., very cursive and scratchy but quite distinct, except towards point where lower line deleted. $91 / 4 " \times 2 \frac{1}{4} " \times 5 / 8$ ". Wood in perfect preservation'.

${ }^{38}$ edeșa vamti literally means 'nearby them, in front of them, against them, next to them', etc. If here edeșa (gen.pl.) is not a scribal error for edes $a$ (gen.sg.), then these people's exact identity is not specified. See infra concerning ghee and śamuta.
} 
(set) in Kroraina ${ }^{39}$ there are mares in a pasture. In the pasture, there Kolýisa and Sugita go hunting. Those royal mares disappeared (or: were lost). This year the detective Apruya was appointed (to investigate there). They were (still) stealing. ${ }^{40}$ And recently ${ }^{41}$ Lýipeya was appointed for the fourth year. They were (still) stealing. Only right now they expose (their misbehaviour) evidently: Kolýisa's own slave drives (or: chases up) the stolen (mares) by rope. When this sealed wedge-tablet reaches (you) there, forthwith Kolýisa and Sugita are to be prevented from going hunting in the pasture. The dispute about the stolen ghee is to be carefully investigated with sworn testimony. Also as regards to the śamuta, inquiry must be carefully made by you in person and a decision is to be made according to law; if you are not clear about it there, they must be sent here in custody.

[Object] In respect to Lýipeya the Cozbo.

\section{Discussion}

One may question the absence of ghrida 'ghee' (Skt. ghrta) and the hapax śamuta in SI 3663, since both were mentioned by the king in KI No. 15. Nevertheless, another double-wedge document $K I$ No. 13 (N. i. $15+107$ ), also concerning improper usage of pasture, speaks for an underlying connection between loss of mares and horses and that of ghee. The main text of No. 13 is extracted as follows:

... ahono iśa $\left.\right|^{\mathrm{U} .0 .2}$ Pugo vimñaveti. yatha etas a kabhoḍami vadavi storam ca, taha jamna tatra nāirira gachamti. vadavi aśpa vijamti. avi tatra ghrida nața. yahi eda kila ${ }^{13}$ mudra atra eśati ... yatha dharmena niče kartavo. ${ }^{14}$ jamna varidavo. ma im ci bhuya nac̄ira gachamti. ${ }^{\mid C . R .1}$ ye jamna tatra nac̄ira gadamti: Yitaka Oga ? Sucamma Vaṃto Opgeya Cinamașa ca. "Pugo informs

\footnotetext{
${ }^{39}$ Local law may differ from one province/state (raja) to another, cf. KI No. 229: yatha purva atra tumah $\left({ }^{*} u\right)$ rajammi dharma vyavasthavidaga siyati, tena vidhanena nice kartavya 'according as [sic] the law has been fixed of old in your province, in that manner a decision is to be made' (TKD: 43).

${ }^{40}$ Another possible interpretation of this recurring phrase in the same line is, 'They were still hiding their pilfrage'.

${ }^{41}$ Here ahuno (Skt. adhunā), lit. 'now', is to be contrasted with sudha ahuno, lit. 'only now, just now' in the following sentence. It seems that the document SI 3663 was written either at the turn of the 3rd and the 4th year of a certain king, or only in his 4th year, who may be identified with Vașmana or his predecessor Mahiri given the prosopographical data of Kolýisa and Sugita collected by PADWA $(2007: 314,331)$
} 
now here that in his pasture there are mares and horses. There the people go hunting. They wound the mares and horses. Also some ghee there has been lost. ... a decision is to be made (by you) according to law. The people are to be prevented. They shall not go hunting anymore. The people who went hunting there were Yitaka, ..., Opgeya and Cinama."

The word śamuta in KI No. 15 is not translated in $T K D$, but in $L K D$ Burrow indicated the possibility to identify it with another obscure word śamuda. The latter is mentioned once together with meat (KI No. 252) and once in contrast to felt garments ( $K I$ No. 387), so perhaps it is another product of animal husbandry. In SI $3663+K I$ No. 15, the absence of ghrida and śamuta in Lýipeya's report may be explained by the ongoing investigation. In other series of double-wedge documents, for example KI Nos. 58 and 63, the king - or his scribe - just simplified the background information in later instructions when the case had been processed for a certain period. So we may assume the existence of earlier records about this matter, too, such as the king's initial order of investigation of the loss in the pasture.

\section{Concluding words}

In addition to the famous Dharmapada collected from Khotan, ${ }^{42}$ SI 3662 and 3663 are the only Kharoșthi material from the southern rim of the Tarim Basin in the SI Collection. Although these two wedge tablets cannot be dated precisely, they are not to be dated to the earlier kings such as Pepiya or Tajaka from prosopographical aspects. As to the provenance, SI 3662 may have been excavated from N. V, which is known to be closely related to Somjaka during his service as a Cozbo officer. ${ }^{43}$ On the other hand, if my pairing of SI 3663 and $K I$ No. 15 (N. i. 17) is correct, SI 3663 was very likely unearthed at the N. I. site. According to Stein, when KI No. 15 was found on 28 January 1901 by himself, it had been already detached and 'lying on the surface of the sand ${ }^{44}$ Moreover, the one who discovered the wooden documents at the Niya sites was a young villager Ibrāhīm, just about one year ago. ${ }^{45}$ If local villagers

\footnotetext{
${ }^{42}$ Cf. Vorobiova-Desiatovskaia 2004: 361; Pecshery Tysyachi Budd 2008: 107.

${ }^{43}$ See Meng 1995: 371; PADWA 2007: 156, 332.

${ }^{44}$ See STEIN 1907: 318.

${ }^{45}$ STEIN 1907: 312-316. This villager is not to be confused with Ibrahim Mullah, an antique trader in Khotan that apparently specialized in the Russian market as an accomplice of the famous forager Islam Akhun, cf. STEIN 1903: 476; Sims-WilLiams 2003: 118.
} 
told him everything they knew, one may imagine that SI 3662 and 3663 were either collected by Ibrāhīm himself, ${ }^{46}$ or by someone between Ibrāhīm's discovery and Stein's first excavation, or even by someone afterwards until Petrovsky resigned his position in Kashghar in 1903. In other words, taking SI 3992 and 3993 as holdings of the Petrovsky collection as granted, these tablets were very probably unearthed before Stein's revisit and the arrival of other expeditions. They shall be analyzed together with the ones kept in the State Hermitage Museum in order to give a fuller view of the Russian collection of ancient documents from Chinese Turkestan.

[In my paper collaborated with OGIHARA Hirotoshi, "SI 3656 and other Kuchean tablets related to the Kizil grottoes in the St. Petersburg Collection". Written Monuments of the Orient, 2016(2), 44-67, the new shelf number of SI P 139/д (= SI 3668) is wrongly given as SI 3669 by mistake. We apologize to all the readers for our error.]

\section{References}

Burrow, Thomas 1934: "Iranian Words in the Kharoșthī Documents from Chinese Turkestan". Bulletin of the School of Oriental Studies, 7 (1933-1935), 509-516.

CHING Chao-jung 慶昭蓉 2012: “Eguo guoli Ai'ermitashi bowuguan suocang qulu wenzi ji poluomi wenzi mujian” 俄國國立艾爾米塔什博物館所藏佉盧文字及婆羅謎文字木簡” [Kharoșṭhī and Brāhmī wooden pieces kept in the State Hermitage Museum, Russia]. Xiyu Wenshi 西域文史 [Literature \& History of the Western Regions], 7 (2012), 19-41.

CHING Chao-jung 2013: "Reanalyzing the Kuchean-Prākrit tablets THT4059, THT4062 and SI P/141". Tocharian and Indo-European Studies, 14 (2013), 55-94.

CHING Chao-jung 慶昭蓉 2017: Tuhuoluoyu shisu wenxian yu gudai Qiuci lishi 吐火羅語世俗 文獻與古代龜茲歷史 [Tocharian Secular Texts and History of Ancient Kucha]. Beijing: Peking University Press.

EMmErick, Ronald E. and Vorobiova-DesiatovskaiA M.I. 1993: Saka Documents. Vol. VII:

The St. Petersburg Collections. Corpus Inscriptionum Iranicarum. London: British Library.

Emmerick, Ronald E. and Vorobiova-Desiatovskaia M.I. 1995: Saka Documents Text. Vol. III: The St. Petersburg Collections. Corpus Inscriptionum Iranicarum. London: British Library.

\footnotetext{
${ }^{46}$ As described by STEIN 1907: 312, initially Ibrāhīm 'brought away half a dozen or so, only to throw some away on the road and to give the rest to his children to play with. Of the latter tablets only one could be recovered next morning'. Finally, Stein acquired 7 pieces ( $=K I$ Nog. 421-427) in 1901, but several more would have been lost from villagers' hands.
} 
Glass, Andrew 2000: A Preliminary Study of Kharoșthī Manuscript Paleography. Master thesis, University of Washington.

GLASS, Andrew 2013: "Bha”. Bulletin of the Asia Institute, 23 (2009[2013]), 79-86.

JAMISON, Stephanie W. 2000: "Lurching towards ergativity: Expressions of agency in the Niya documents." Bulletin of the School of Oriental and African Studies, 63 (2000), 64-80.

$K I$ = BOYER, A.M., RAPSON Edward J., SÉNART, Émile and NOBLE P.S. 1920-1929: Kharoșthī Inscriptions Discovered by Sir Aurel Stein in Chinese Turkestan. Oxford: Clarendon.

LKD = BuRrow, Thomas 1937: The Language of the Kharosthi Documents from Chinese Turkestan. Cambridge: Cambrdige University Press.

Malzahn, Melanie 2007: “Tocharian texts and where to find them". In Instrumenta Tocharica. Ed. by M. Malzahn. Heidelberg: Winter, 79-112.

MENG Fanren 孟凡人 1995: Loulan Shanshan jiandu niandaixue yanjiu 樓蘭鄯善簡牘年代學 研究. Urumqi: Xinjiang Renmin chubanshe.

$M W=$ MonIER-WILlaims, Monier 1899: Sanskrit-English Dictionary. Oxford: Clarendon.

PADWA, Mariner Ezra 2007: An Archaic Fabric: Culture and Landscape in the Early Inner Asian Oasis (3rd-4th Century C.E. Niya). Dissertation thesis, Harvard University.

Pecshery tysiachi budd 2008: Peshchery tysiachi Budd. Rossiiskiie ekspeditsii na Shelkovom Puti. K 190-letiiu Aziatskogo muzeia. Katalog vystavki. SPb.: Izdatel'stvo Gosudarstvennogo Ermitazha [The Caves one thousand Buddhas. Russian expeditions along the Silk Route. On the Occasion of 190 Years of the Asiatic Museum. Exhibition catalogue. St. Petersbuerg: The State Hermitage Publisher].

Popova, Irina F. 2008: "Russian expeditions to Central Asia at the turn of the $20^{\text {th }}$ century". In Russian Expeditions to Central Asia at the Turn of the 20th Century. Ed. by I.F. Popova. St. Petersburg: Slavia, 11-39.

RHIE, Martin M. 1999: Early Buddhist Art of China and Central Asia, vol. I. Leiden: Brill.

SCHMIDT, K.T. 2001: "Entzifferung verschollener Schriften und Sprachen dargestellt am Beispiel der Kučā-Kharoșṭ̂̄ Typ B und des Kučā-Prākrits". Göttinger Beiträge zur Asienforschung, 1 (2001), 7-27.

SEIPEL, Wilfried 1996: Weihrauch und Seide. Alte Kulturen der Seidenstraße. Wien: Wasmuth Ernst.

SimS-WILliams, Ursula 2003: "Forgeries from Chinese Turkestan in the British Library's Hoernle and Stein Collections." Bulletin of the Asia Institute, 14 (2000[2003]), 111-129.

SteIn, Aurel M. 1903: Sand-buried Ruins of Khotan. London: T. Fisher Unwin.

SteIn, Aurel M. 1907: Ancient Khotan. Detailed Report of Archaeological Explorations in Chinese Turkestan. Oxford: Clarendon.

TKD = BuRRow, Thomas 1940: A Translation of the Kharosthi Documents from Chinese Turkestan. London: Royal Asiatic Society.

Vorobiova-DesiatovskaiA, Margarita I. 1997: "The ancient manuscripts from Eastern Turkestan in the St. Petersburg". Tocharian and Indo-European Studies, 7 (1997), 205-212.

Vorobiova-Desiatovskaia, Margarita I. 2004: "The role of N.F. Petrovsky in the formation of the Central Asiatic Manuscript Collection of the St. Petersburg Branch of the Institute of Oriental Studies". In Turfan Revisited. The First Century of Research into the Arts and Cultures of the Silk Road. Ed. by D. Durkin-Meisterernst, S.-Ch. Raschmann, J. Wilkens, M. Yaldiz and P. Zieme. Berlin: Dietrich Reimer, 361-362. 
Vorobiova-Desiatovskaia, Margarita I. 2006: "The Central Asian Manuscript Collection of the St. Petersburg Branch of the Institute of Oriental Studies of the Russian Academy of Sciences". Annual Report of the International Reasearch Institute for Advanced Buddhology at Soka University, 9 (2006), 61-78.

WEBER, Dieter 1997: "Iranian loans in the Niya documents re-examined". In Languages and Scripts of Central Asia. Ed. by Sh. Akiner and N. Sims-Williams. London: School of Oriental and African Studies, 30-38. 